\section{Linking e-hrm practices and organizational outcomes: empirical analysis of line manager's perception}

\author{
Naveed Iqbal ${ }^{1}$ \\ ${ }^{1}$ COMSATS University Islamabad, \\ Department of Management Science, Abbottabad, Pakistan \\ Mansoor Ahmad ${ }^{2}$ \\ Muhammad Mustafa Raziq ${ }^{2}$ \\ ${ }^{2}$ COMSATS University Islamabad, \\ Department of Management Science, Islamabad, Pakistan
}

Felipe Mendes Borini ${ }^{3}$

${ }^{3}$ University of Sao Paulo, São Paulo, Brazil
Received on:

$11 / 14 / 2017$

Approved on:

$08 / 22 / 2018$

\section{Responsible Editor:}

Prof. Dr. João Mauricio Gama

Evaluation process:

Double Blind Review

\begin{abstract}
Purpose - This study seeks to explore the value creation opportunities offered by e-HRM practices. The purpose of this paper is to examine the impact of operational, relational, and transformational e-HRM practices on organizational outcomes by incorporating HRM service quality as an intermediary value creating factor.
\end{abstract}

Design/methodology/approach -Line managers of commercial banks that adopted operational, relational, and transformational e-HRM were asked to participate in the study. The study used exploratory factor analysis for scale validation. PLS-SEM was used to validate and test the conceptual model.

Findings - Drawing on data from a large and new survey, the study found that operational, relational, and transformational e-HRM practices have a significant impact on HR service quality and employee productivity. HRM service quality mediates the relationship between e-HRM practices and organizational outcomes.

Implications - The study focuses on the relevance of e-HRM practices for improving organizational effectiveness, leading to competitive advantage for the firm. It is one of the pioneering studies that explore the link between e-HRM practices and organizational outcomes by analyzing the perception of South Asian line managers from the banking sector. Organizations from developing and developed countries can extract benefits by designing and implementing e-HRM systems in a way that supports their workflow.

Keywords: e-HRM practices; Employee productivity; Quality of HR services; Operational, relational, and transformational e-HRM.

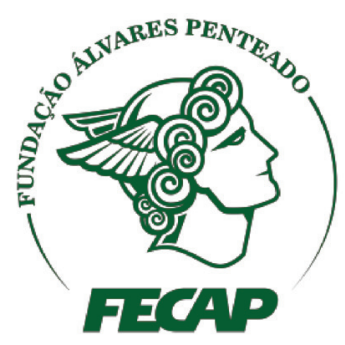

\section{Review of Business} Management

DOI: $10.7819 /$ rbgn.v21i1.3964 


\section{Introduction}

Advances in information and communication technologies have led to new information technology-based management systems. Due to the availability of these management information systems, the HRM function faces exceptional pressure to become more efficient, productive, innovative, and capable of supporting strategic objectives, creating a new e-HRM approach. Indeed, the latest advances in technology have had a significant impact on HR processes, leading to a "real-time, informationbased, self-service, interactive work environment" (Lengnick-Hall \& Moritz, 2003, p. 365) that aims to create value for organizational stakeholders (Bondarouk \& Ruel, 2009; Ruel, Bondarouk, \& Van der Velde, 2007). Such systems have many potential benefits for organizations, such as operational efficiency, enhanced quality of HR processes, cost reduction, better delivery of HRM services, and transformation of the HR function into a strategic partner (Bondarouk \& Ruel, 2009; Lepak \& Snell, 1998; Marler, 2009; Strohmeier, 2007). The broader focus of existing studies has remained on investigating micro-level issues. For instance, prior research has often used the technology acceptance model as a theoretical perspective in e-HRM studies.

Very few studies draw on the resourcebased view of the firm (RBV) to examine the effects of e-HRM on workplace outcomes (Marler $\&$ Fisher, 2013). Previous studies (Bondarouk, Schilling, \& Ruel, 2016; Marler \& Fisher, 2016; Panos \& Bellou, 2016; Wahyudi \& Park, 2014) have acknowledged that e-HRM can create value by increasing the efficiency of HR activities, improving HR service delivery, and transforming the role of the HR function into one that is more strategic. If this is true, then e-HRM may create value and contribute to the success of the firm. Therefore, the extensive deployment of technology-enabled HRM could be an additional source of rents. Human resources can lead to sustainable competitive advantage because the distinctiveness of human beings compared to other resources is constituted on the basis of their ability to learn, transfer knowledge, and make productive use of resources (Penrose, 1959). e-HRM can provide a platform for the effective utilization of resources, resulting in superior firm performance (Lengnick-Hall, Lengnick-Hall, Andrade, \& Drake, 2009; Ulrich \& Brockbank 2005), and making the RBV framework a suitable one for assessing if e-HRM can enhance organizational performance (Marler, 2009; Marler \& Fisher, 2013; Parry, 2011). This study draws on RBV theory to investigate the role of e-HRM practices in improving the quality of $\mathrm{HR}$ services and employee productivity, an important organizational outcome.

Firms seek to improve capability and processes through the deployment, development, and management of HR, which is imperative for achieving strategic goals (Parry, 2011; De Winne \& Sels, 2003). Enhancing the productivity of the workforce is a key to achieving superior performance (Delery \& Shaw, 2001). In particular, HR service quality has been considered a key variable for employee satisfaction and the productivity of employees as internal customers (Uen, Ahlstrom, Chen, \& Tseng, 2012; Zheng \& Lamond, 2010). Existing research has suggested an association between e-HRM and the quality of HR services (Wahyudi \& Park, 2014); however, the quality of HR services (QHRS) is not an ultimate objective for organizations (Uen et al., 2012). Unfortunately, previous research on e-HRM has generally ignored the impact of e-HRM practices on organizational-level outcomes, such as employee productivity (Marler $\&$ Fisher, 2013). This research aims to fill this gap by investigating whether operational, relational, and transformational e-HRM practices improve employee productivity in the workplaces of commercial banks in Pakistan.

Research on e-HRM practices is relatively limited. Moreover, the existing e-HRM models have been developed in Europe and the United States. These studies may, therefore, reflect 
westernized attitudes and beliefs. To date, very little is known about the use of e-HRM and its impact on organizational outcomes in South Asia, in particular. The banking sector in Pakistan is important for several reasons. First, it is expected to remain a strong contributor to the economy (KPMG, 2013). Second, it is one of the most profitable sectors of the economy (Khan, 2009), facilitating the use of the latest management trends and technology. Third, there has recently been an upsurge in the use of e-HRM practices in banks as top management has focused on the quality of HR processes and productivity to improve competitiveness (Bashir, 2015; Khan, Rehman, Rehman, Safwan, \& Ahmad, 2011).

This study makes several contributions. First, the study enriches the existing literature by examining the impact of e-HRM on employee productivity. Second, it extends existing models by incorporating the role of quality of HR service (QHRS) as a mediator between e-HRM and HRM outcomes. Third, the study provides evidence on the efficacy of e-HRM practices from the banking sector of Pakistan, a sector that has adopted these practices extensively in recent decades. The paper proceeds with a review of the RBV and its application for e-HRM, and explores the linkages between operational, relational, and transformational e-HRM practices, quality of HR service, and employee productivity to develop the hypotheses. Prior to discussing our results, we set out our methodology.

\section{Literature Review}

\section{I Resource-based view of the firm and e-HRM}

The resource-based view of the firm is a major theoretical paradigm that has been used extensively in the strategic HRM literature. It emphasizes building competitive advantage through capturing economic rents stemming from fundamental firm-level efficiency advantages by exploiting internal resources and developing organizational capability (Barney, 1991; Penrose, 1959; Wernerfelt, 1984).

Thus, the RBV provides a useful framework for establishing associations between HRM and organizational performance. The RBV thus accords a direct and strategic role for HRM. It focuses on internal factors and postulates that the performance of a firm is the result of its resources and capabilities.

Boselie, Dietz, and Boon (2005) reported that one third of HRM-performance empirical studies from 1994 to 2003 used the RBV as a theoretical framework. Koch and McGrath (1996) looked at the impact of HR on employee productivity in US business units. They build on the RBV by recommending that a positive association exists between sophisticated HRM systems and employee productivity. Huselid (1995) also confirms the link between HRM and employee productivity and turnover. A key study that draws on the RBV to investigate the links between e-HRM practices and organizational performance is the one by Parry (2011).

The RBV encompasses two key assumptions (Deb, 2009). First, human capital is a valuable asset that is critical for organizational success. Second, resources should be transformed, using routines, into organizational capability. Firm resources and skill on their own do not guarantee sustainable competitive advantage (SCA). Similarly, HRM practices are critical for achieving competitive advantages; however, these practices are not sufficient for SCA. Competitive advantage can be sustained where organizations are able to effectively implement HR systems and make them integral to their strategies. Deb (2009) claims that the same can be achieved when resources, processes, and activities are combined into a system that represents a collective learning system. This study argues that one way of doing this is for an organization to introduce a comprehensive e-HRM system.

e-HRM practices enable organizations to integrate, assemble, and make productive use of inimitable resources as well as enhance their 
capabilities, resulting in superior productivity and firm performance (Lengnick-Hall \& Lengnick-Hall, 2006; Ulrich \& Brockbank, 2005). Superiority comes from productive and differentiated employees both in secondary and primary value-chain activities (Koch \& McGrath, 1996; Parry, 2011). Such human capital fits the spirit of the RBV. These practices can accrue returns for organizations by providing quality services to internal customers and as a result improve employee productivity and lower costs (Coronas \& Oliva, 2009; Parry \& Tyson, 2011). The study tests whether e-HRM practices improve employee productivity by providing quality services to internal customers.

\subsection{Operational, relational, and transformational e-HRM}

e-HRM does not play a specific role in the development of HRM, but offers a set of approaches to HRM. Generally, HRM refers to a set of activities undertaken by a firm for the effective utilization of human capital (LengnickHall \& Moritz, 2003) and these activities can be divided into three main categories: transactional activities (derived from operational impact), traditional activities (derived from relational impacts), and transformational activities (derived from transformational impact) (Noe, Colquitt, Simmering, \& Alvarez, 2003; Parry \& Tyson, 2011). Taking the same analogy, Bissola and Imperatori (2013) suggested that e-HRM practices can be grouped into operational, relational, and transformational e-HRM practices. There are two types of e-HRM studies identified in the literature. The first set of e-HRM studies, such as Bissola and Imperatori (2013), examines the individual impact of operational, relational, and transformational e-HRM practices on value outcomes. The second set of e-HRM studies focus on an integrated view of e-HRM for operational, relational, and transformational impact. Following the Bissola and Imperatori (2013) e-HRM practices classification, this study aims to examine the individual effect of each type of e-HRM practices. Table 1 shows the classification of e-HRM practices.

Operational e-HRM practices are concerned with the administrative role of the HR function. Such practices are also called zero level or obligatory practices because these are usually considered essential for the existence of the HR function (Maatman, Bondarouk, \& Looise, 2010). Workplaces use operational or zero level e-HRM practices to achieve 'transactional goals', including, inter alia, productivity improvements and reducing the cost of $\mathrm{HR}$ activities (Bissola \& Imperatori, 2013; Strohmeier, 2007).

Second, relational e-HRM practices are focused on inter-personal relationships. Bissola and Imperatori (2013, p. 453) described relational e-HRM practices as a tool "to manage the relationship between organizations and their employees". The purpose of such practices is twofold: first, they improve the quality of HR services, and second, they ensure procedural and organizational justice by empowering employees and managers (Payne, Horner, Boswell, Schroeder, \& Stine-Cheyne, 2009; Parry \& Tyson, 2011). By contrast, transformational e-HRM concerns e-HRM practices with a 'strategic character' to align employee attitudes and behavior with the organization's strategy (Bissola \& Imperatori, 2013; Bondarouk \& Ruel, 2009; Marler, 2009; Parry \& Tyson, 2011). 
Table 1

\section{Classification of e-HRM practices}

\begin{tabular}{llll}
\hline Source & Operational Practices & Relational Practices & Transformational Practices \\
\hline $\begin{array}{l}\text { Snell, Pedigo, and } \\
\text { Krawiec (1995) }\end{array}$ & $\begin{array}{l}\text { Information, making information } \\
\text { available, and using it for decision } \\
\text { support }\end{array}$ & $\begin{array}{l}\text { HR databases, supporting HR-related } \\
\text { decisions, and increasing abilities in } \\
\text { other parts of the organization }\end{array}$ & $\begin{array}{l}\text { Restructuring, outsourcing, } \\
\text { and strategic alliances created } \\
\text { by the organization }\end{array}$ \\
\hline $\begin{array}{l}\text { Lengnick-Hall and } \\
\text { Moritz (2003). }\end{array}$ & Publishing information & Automation of transactional workflow & $\begin{array}{l}\text { Transformation of the way } \\
\text { HRM is conducted in the firm }\end{array}$ \\
\hline $\begin{array}{l}\text { Lepak, Bartol, and } \\
\text { Erhardt (2005) }\end{array}$ & $\begin{array}{l}\text { Benefit administration, record } \\
\text { keeping, employee services, } \\
\text { communication }\end{array}$ & $\begin{array}{l}\text { Performance management, recruiting, } \\
\text { training, compensation }\end{array}$ & $\begin{array}{l}\text { Knowledge management, } \\
\text { organizational development, } \\
\text { strategic planning }\end{array}$ \\
\hline $\begin{array}{l}\text { Sanayei and Mirzaei } \\
(2008)\end{array}$ & $\begin{array}{l}\text { Pecruitment and selection, } \\
\text { performance appraisal and } \\
\text { management, skills management, } \\
\text { training management, grievance } \\
\text { management }\end{array}$ & $\begin{array}{l}\text { Succession planning and talent } \\
\text { management }\end{array}$ \\
\hline $\begin{array}{l}\text { Parry and Tyson } \\
(2011)\end{array}$ & $\begin{array}{l}\text { Payroll, administrative HR } \\
\text { practices }\end{array}$ & $\begin{array}{l}\text { Performance management, } \\
\text { recruitment and selection, learning } \\
\text { and training. }\end{array}$ & $\begin{array}{l}\text { Strategic orientation, } \\
\text { knowledge sharing }\end{array}$ \\
\hline $\begin{array}{l}\text { Bissola and Imperatori } \\
(2013)\end{array}$ & $\begin{array}{l}\text { Record keeping, payroll, benefit } \\
\text { management }\end{array}$ & $\begin{array}{l}\text { Recruitment, learning and training, } \\
\text { performance appraisals, compensation } \\
\text { management }\end{array}$ & $\begin{array}{l}\text { Knowledge management, firm } \\
\text { communities }\end{array}$ \\
\hline
\end{tabular}

\section{Hypotheses Development}

\section{I Employee productivity}

In today's competitive world, organizations place emphasis on employee productivity improvement strategies (Qutaishat, Khattab, Zaid, \& Al-Manasra, 2012). Productivity has been recognized as a key value outcome in the IT business value literature for superior firm performance and to achieve competitive advantage (Lempinen \& Rajala, 2014). Organizations use HRM technologies aiming to boost employee productivity (CedarCrestone, 2013). Theoretical support for such propositions has been found in IT business value research and the HRM literature. e-HRM offers opportunities to the human resources of organizations to enhance their capabilities, leading to improved employee productivity (Bissola \& Imperatori, 2013; Bondarouk \& Ruel, 2013; Marler \& Fisher, 2013; Panos \& Bellou, 2016; Snell \& Dean, 1992). e-HRM also increases productivity through automation and replacing low-value administrative tasks with high value-added tasks
(Marler \& Parry, 2016). It also provides quick, updated, and reliable information to managers for them to make appropriate decisions.

A management system based on technology creates opportunities for the human resources of organizations to enhance their capabilities and contribute to the success of the organization (Snell \& Dean, 1992). If innovative approaches to HRM increase organizational performance, then e-HRM seems a good fit for superior organizational performance, in terms of enhanced employee productivity. Employee productivity is referred to as the "extent to which a firm's labor force is efficiently creating output." (Ejaz, 2012, p. 38).

According to the SHRM and e-HRM literatures, it is appropriate to differentiate between e-HRM practices on the basis of the value they add to the organization (Parry \& Tyson, 2011). Youndt, Snell, Dean, and Lepak (1996) suggested that different HRM practices influence organizational outcomes in different ways, indicating that e-HRM practices may play different roles in the enhancement of employee productivity. Generally, firms introduce e-HRM 
practices to achieve operational, relational, and transformational goals.

A shift in approach for the delivery of transactional-HRM from employee-intensive to technology-intensive has been noted in how transactional HRM tasks are performed through technology-enabled HRM practices. Operational e-HRM practices increase the efficiency of organizations by streamlining transactional HRM activities, speeding up processes and reducing headcounts (Lepak \& Snell, 1998; Parry, 2011). Such practices provide efficient and alternative ways to performing transactional HR processes more accurately and effectively, leading to a reduction in staff numbers and potentially contributing to an increase in employee productivity (Martin, Reddington, \& Alexander, 2008). One recent study reported that e-HRM practices increase both cost and time efficiencies and are expected to enhance employee productivity (Parry, 2011). e-HRM can reduce costs and save employees' time by "allowing more transactions to occur with fewer fixed responses" and, as a result, improve employee productivity (Hendrickson, 2003, p. 383). Therefore, we propose that workplaces within commercial banks that implement operational e-HRM will have better employee productivity.

H1a: Operational e-HRM practices are positively and directly associated with employee productivity.

HR strategy and practices develop organizational capability by developing and supporting employees' knowledge, skills, and relationships inside the organization (Snell, Stuebner, \& Lepak, 2002). Some authors have suggested that the primary focus of HR practices is to create a positive employment relationship (Bissola \& Imperatori, 2013; Lengnick-Hall \& Moritz, 2003) and have explored the relational implications of HRM practices (Bissola \& Imperatori, 2013; Evans \& Davis, 2005). Relational e-HRM practices do not just mean the 'digitization' of traditional HR practices and systems, but provide new management styles that create relationship opportunities (Bissola \& Imperatori, 2012; Marler, 2009), which have a significant and positive impact on employee productivity by improving HR services and empowering employees (Bissola \& Imperatori, 2013). Thus, we propose that:

H1b: Relational e-HRM practices are positively and directly associated with employee productivity.

Transformational practices focus on talent management and employee development. They include practices such as knowledge management, HR planning, and talent acquisition and management. In spite of some discussion in the literature about the potential impact of e-HRM, it is still not clear whether transformational e-HRM significantly contributes to the achievement of strategic outcomes, such as employee productivity. These practices do not always emphasize employee outcomes directly, but generally aim to align employees' behavior with organizational outcomes. Such a consideration is relevant for organizations, such as banks, which have widely scattered units/branches where transformational e-HRM practices can be utilized to align employees' attitudes with the banks' goals and to enhance employees' abilities and competencies. We thus argue that e-HRM practices can provide the necessary conditions to help improve employee productivity (Bissola \& Imperatori, 2013; Parry \& Tyson, 2011). Therefore, we hypothesize that:

H1C: Transformational e-HRM practices are positively and directly related with employee productivity.

\subsection{Quality of HR services}

Organizational goals could be enhanced by addressing internal customer satisfaction through improvements in service quality (Marler 
\& Parry, 2016; Soteriou \& Stavrinides, 2000; Uen et al., 2012). The delivery of quality services is imperative for the satisfaction of internal customers because it directly influences their motivation. It supports the routines, processes, and activities of the functional division. Internal service quality describes the level of support and assistance offered by the firm to its employees (Liao et al., 2009). The IEEE Standard Glossary (IEEE STD 610.121990) defines quality with regard to software in terms of the software's compound characteristics as determinants of meeting customer expectations.

Ehrhart, Witt, Schneider, and Perry (2011) utilize the concept of service quality to investigate internal service quality in branches of banking organizations. Researchers and practitioners have shown a keen interest in service quality in order to evaluate performance; however, the existing literature pays relatively limited attention to the quality of services within HRM contexts, including, most recently, the introduction of e-HRM (Wahyudi \& Park, 2014). Theoretically, e-HRM improves the QHRS as it enables a firm to provide standard and errorless HR services to internal customers that may ultimately help the employees to focus more on their core duties and thus have a positive effect on employee productivity. Certain studies present positive views about the relationship between e-HRM and HR service quality. For example, Wahyudi and Park (2014) found that e-HRM usage is a strong predictor of HR service quality. Parry (2011) argued that e-HRM practices can increase the quantity and quality of the services that HR provides to the organization. Ramezan, Nazari, and Ahmadi (2013) found that operational and relational e-HRM practices have a positive and significant effect on the quality of HR processes. Wahyudi and Park (2014) suggested a direct relationship between e-HRM practices and the quality of HR services. e-HRM plays a key role in improving the quality of services by enforcing a climate for services and facilitating HR-service delivery. Therefore, we hypothesize that workplaces within commercial banks that take more interest in providing quality $\mathrm{HR}$ services will have a higher rate of adoption of relational, operational, and transformational e-HRM practices.

H2a: Higher adoption rates of operational e-HRM practices are positively associated with HR service quality.

H2b: Higher adoption rates of relational e-HRM practices are positively associated with HR service quality.

H2a: Higher adoption rates of transformational e-HRM practices are positively associated with HR service quality.

Quality of HR services (QHRS) plays a central role in investigating the e-HRMperformance relationship regardless of perception and cultural differences. HR quality is at the center of the e-HRM-performance causal chain. Uen et al. (2012) described the above idea in terms of 'HR input quality', 'HR process quality', and 'HR output quality' and proposed that such dimensions are essential for a comprehensive 'HR service quality' framework. First, HR output quality is an important aspect of the quality of the HR system and refers to what is produced as a result of providing a service; whereas HR process quality describes the "quality of interaction between service provider and internal customer" (Johnson et al., 1995 apud Uen et al., 2012, p.7) and provides reliable services for the internal customer; while HR input quality refers to the structure, equipment, and practices that support the services (Uen et al., 2012). If HR services are provided with innovativeness, customization, and comprehensiveness to internal customers, they will satisfy their needs, increase job performance and the focus on core activities, and ultimately enhance employee productivity (CedarCrestone, 2012; Uen et al., 2012). Based on the above discussion, the study argues that e-HRM practices 
(HR input service quality) increase the quality of HR services (HR process service quality), which in turn increases employee productivity (HR output service quality) (Uen et al., 2012). Many studies (Bondarouk et al., 2016; Ramezan et al., 2013; Wahyudi \& Park, 2014) have empirically found a relationship between e-HRM practices and quality of HR services; however, some research suggests that we need to know more about how QHRS influences the impact of HRM practices and policies on key workplace outcomes (Meijerink, Bondarouk, \& Lepak, 2016; Uen et al., 2012). Therefore, the study extends the existing model by analyzing the mediating impact of QHRS between operational, relational, and transformational e-HRM and employee productivity. We argue that QHRS plays a significant mediation role in the association between operational, relational, and transformational e-HRM practices, on the one hand, and employee productivity, on the other hand.

H3: QHRS mediates the relationship between operational, relational, and transformational e-HRM practices and employee productivity.

\section{Research Design}

\section{I Context of the study}

Due to a lack of universal e-HRM practices, the use of e-HRM practices varies from country to country and industry to industry (Iqbal, Ahmad, Allen, \& Raziq, 2018; Obeidat, 2016). Bondarouk et al. (2016) and Iqbal et al. (2018) argue that there is limited empirical evidence on the e-HRM value creation proposition from the developing country context. Research suggests that country specific empirical evidence is essential to conclude the e-HRM value creation debate (Ahmad \& Allen, 2015; Panayotopoulou, Galanaki, \& Papalexandris, 2010). Therefore, empirical findings drawn from western studies are not easily generalizable with regard to developing countries. Conducting research in multiple sectors or industries with different competitive environments may in some cases deviate or confuse the research (Becker \& Gerhart, 1996). Single-industry studies enable researchers to identify the key competitive metrics that participants within the industry consider important, and assess the unique strategies that organizations engage in as a means of increasing performance in those metrics, which is quite relevant to the e-HRM performance debate. In order to benefit from a single industry analysis, we decided to select our sample from the banking industry in Pakistan.

Pakistan is a South Asian country with a population of approximately 200 million. Banking organizations in Pakistan represent 95\% of the financial sector and the country has secured $46^{\text {th }}$ position out of 55 for banking soundness (Blanke \& Chiesa, 2009). The history of the banking sector in Pakistan can be categorized into prenationalization, nationalization, and privatization stages. In the privatization evolutionary stage, many state-owned banks were privatized to increase the efficiency of such banks and to overcome problems such as high administration costs and low employee productivity and customer service. The government of Pakistan revised the nationalization law and as a result transferred the ownership of a few public banks to the private sector. In 1990, the share of the private banks increased significantly (i.e. $45.5 \%$ ). The postprivatization era has witnessed an outdated system and inefficient utilization of key organizational resources such as human resources, which are key concerns for the banks (Burki \& Niazi, 2009). It is imperative to have competent, productive, and knowledgeable employees for the development of private banks. The focus of this research is private banks in Pakistan. There are 17 private banks operating in Pakistan. As above, limited empirical evidence exists regarding the value creation of operational, relational, and transformational e-HRM practices. 


\subsection{Data}

There are no secondary data sources for examining how e-HRM influences workplace outcomes in Pakistan. Indeed, there are few quantitative studies of any kind on HRM within Pakistani workplaces and those that do exist do not cover e-HRM (Ahmad \& Allen, 2015). Seventeen commercial banks operate in Pakistan (State Bank of Pakistan, 2013). Multistage sampling is more suitable for a large-scale enquiry covering a comparatively wide geographical area (Mustafi et al., 1999). We used purposive sampling for bank city selection whereas random sampling was used to identify branches within the selected bank cities. From each of the selected branches, we randomly chose a number of senior managers to be the ultimate sample to provide information. For the study, we selected only those banks that fulfill the following criteria: (a) they must have an e-HRM system that has been functioning for at least one year; and (b) they must have implemented the three different types of e-HRM practices i.e. operational, relational, and transformational e-HRM practices. Bondarouk, Harms, and Lepak (2017) and Ruël et al. (2004) suggest that one year of e-HRM system maturity creates a comfortable research zone. In this research, we ensure that no bank is selected where e-HRM practice maturity is less than a year. Therefore, we select banks where e-HRM has been used for more than one year. Iqbal et al. (2018) suggest that line managers are central to interpreting e-HRM value creation. Purcell and Hutchinson (2007) highlight the importance of the perceptions of line managers to explaining the HRM-performance causal chain. Branch managers are presumed to be more knowledgeable about their workforces. e-HRM is a multilevel construct that creates value at different levels (Bondarouk \& Ruel, 2013; Strohmeier, 2007). e-HRM influences both micro and macro level consequences (Strohmeier, 2007). Micro level consequences describe individual level impacts, while macro level consequences refer to organizational outcomes (Strohmeier \& Kabst, 2009). Employees and managers are also used as units of analysis to explore the e-HRM value creation proposition. The former is used to explore micro level consequences, while the latter is employed for macro level consequences. This study emphasizes branch level performance; therefore, branch managers are a more appropriate unit of analysis here to test the link between e-HRM practices and organizational outcomes.

A structured self-administered questionnaire was sent to 11 banks in Islamabad, Rawalpindi, Peshawar, Lahore, and Karachi. Most commercial activity in Pakistan is concentrated in these cities (Ahmad \& Allen, 2015). These banks have 1024 branches in the cities targeted. Using a random sampling approach, we invited 516 branches to participate in the research. One questionnaire was sent out per branch, requesting that the section on e-HRM should be filled in by the operational manager and the branch performance indicators should be provided by the branch manager. Operational and branch managers comprise branch establishment. Branch managers are responsible for overseeing all branch operations, including staff hiring, training, and supervision. Operation managers coordinate and monitor HR activities in order to ensure the overall efficiency of daily operations. Overall, we received responses from 323 branches of commercial banks.

\section{$4 \cdot 3$ Study measures}

\subsection{Independent variable}

Table 2 provides details of the independent and dependent variables used in this study. Conceptual and empirical work, industry and vendor surveys relating to e-HRM, white papers, and consultant reports were examined to identify the practices and attributes of operational, relational, and transformational e-HRM systems. e-HRM (operational, relational, and transformational) systems include various practices, such as e-payroll, employee self-profiling systems, e-benefits, time schedules, e-attendance registers, e-performance management systems, 
e-recruitment and selection, e-succession planning and career management, e-talent management, e-training, e-grievance management, knowledge creation, access and sharing practices, and firm communities (Bissola \& Imperatori, 2013; Marler, 2009; Marler \& Fisher, 2013; Parry, 2011; Parry \& Tyson, 2011; Ruel, Bondarouk, \& Looise, 2004; Ruel, Bondarouk, \& Van der Velde, 2007; Sanayei \& Mirzaei, 2008). We conducted a small qualitative study to select and finalize the three categories of e-HRM practices that the sampled banks commonly use and prioritize.
The existing literature shows that different studies focus on different e-HRM practices. Furthermore, e-HRM practices can be expected to vary across countries, industries, and organizations. We contacted HR directors from our sample banks to identify the e-HRM activities they use. We shortlisted 11 banks through purposive sampling and we contacted HR directors to gain their feedback about the use of e-HRM practices.

Table 2

\section{Independent variables and factor analysis}

Questionnaire Items

e-HRM has increased the focus of managers $\&$ employees on their core duties.

I believe that the productivity of our employees is better than our competitors.

By using e-HRM, average effective hour loss is decreased.

Since the implementation of e-HRM, average absentee rates have been reduced.

e-HRM has increased the focus of managers $\&$ employees on their core duties.

e-HRM guarantees errorless administration.

e-HRM provides quality HR services to its internal customers (e.g. managers, employees).

Using e-HRM gives me greater control over my work.

Using e-HRM improves the quality of the work I do.

HR services have been streamlined \& standardized in our organization.

e-HRM is used for day to day administrative duties.

e-HRM in my organization is used for attendance $\&$ work schedules.

Managers use e-HRM for managing employee benefits.

I would like to use e-HRM for formal grievances \& complaints.

I would prefer to use e-HRM for online testing \& learning.

e-HRM is used to appraise branch employees in our organization.

e-HRM is used to review the performance of the branch employee.

We use e-HRM for recruitment $\&$ selection processes.

\begin{tabular}{|c|c|c|c|c|c|}
\hline 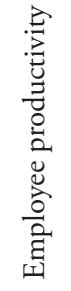 & 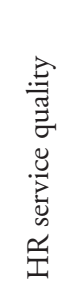 & 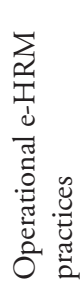 & 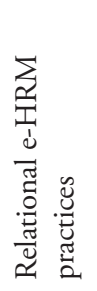 & 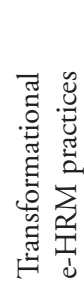 & $\frac{\tilde{J}}{\tilde{z}}$ \\
\hline .759 & \multirow{18}{*}{$\begin{array}{l}.772 \\
.899 \\
.732 \\
.862 \\
.867\end{array}$} & \multirow{18}{*}{$\begin{array}{l}.865 \\
.826 \\
.805\end{array}$} & & & 24.541 \\
\hline .850 & & & & & 46.539 \\
\hline .899 & & & & & 74.540 \\
\hline .835 & & & & & 31.175 \\
\hline \multirow[t]{14}{*}{.829} & & & & & 32.960 \\
\hline & & & & & 23.487 \\
\hline & & & & & 56.353 \\
\hline & & & & & 22.088 \\
\hline & & & & & 44.055 \\
\hline & & & & & 44.427 \\
\hline & & & & & 56.161 \\
\hline & & & & & 27.886 \\
\hline & & & & & 32.290 \\
\hline & & & .599 & & 13.281 \\
\hline & & & .696 & & 18.894 \\
\hline & & & .618 & & 13.942 \\
\hline & & & .791 & & 28.208 \\
\hline & & & .835 & & 40.121 \\
\hline
\end{tabular}




\begin{tabular}{|c|c|c|c|c|c|c|}
\hline Questionnaire Items & 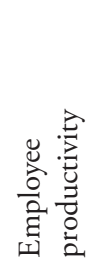 & 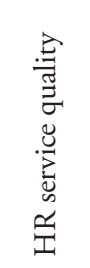 & 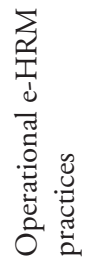 & 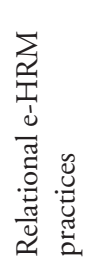 & 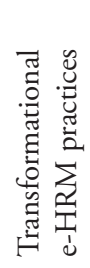 & 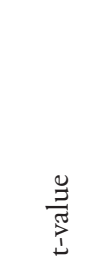 \\
\hline $\begin{array}{l}\text { e-HRM is used to access information about the latest updates in } \\
\text { the banking industry. }\end{array}$ & & & & & .908 & 49.986 \\
\hline $\begin{array}{l}\text { Managers use e-HRM to receive formal information about a wide } \\
\text { range of issues relevant to the branch \& its operation. }\end{array}$ & & & & & .882 & 36.411 \\
\hline Managers use e-HRM for talent management. & & & & & .693 & 12.516 \\
\hline Cronbach's Alpha & .8917 & .8842 & .7819 & .7654 & .7741 & \\
\hline Composite Reliability (CR) & .9204 & .9160 & .8711 & 8363 & 8706 & \\
\hline Average Variance Extracted (AVE) & .6986 & .6869 & .6927 & .5096 & .6945 & \\
\hline
\end{tabular}

\subsubsection{Dependent Variables}

Employee productivity was measured through the subjective judgment of bank managers by borrowing measures from WERS $(2004)^{1}$, Beaton et al. (2009), and the Stanford Presenteeism Scale (2002), with a Cronbach's alpha of 0.8917 indicating the instrument is reliable and consistent. The study could use objective measures for labor productivity; however, only one-third of the sample provided objective data. Due to the limited willingness of the respondents to provide financial data, we relied on the subjective assessment of labor productivity. Patel and Conklin (2012) suggest perceived labor productivity as a valid and reliable measure. Perceived labor productivity has been wieldy used in the literature (Ahmad \& Allen, 2015; Bartel, 1995; Barron, Black, \& Lowenstein, 1993; Beaton et al., 2009; Bryson, Charlson, \& Forth, 2006; WERS, 2004). QHRS consists of five items adapted from Wahyudi and Park's (2014) HR Quality Service Scale - the Cronbach's alpha score of that is 0.8842 here.

\section{$4 \cdot 3 \cdot 3$ Control variables}

The inclusion of control variables is one of the suggested approaches for model robustness (Khilji \& Wang, 2007). Organization size and organization age were used as control variables to enhance the robustness of the results. The effect of the two control variables, i.e. organization age and organization size, was estimated to minimize the spurious impact on the endogenous variable.

\subsubsection{Data analysis}

Structural equation modeling was employed to analyze the data. The data were analyzed using two sequential processes to examine the causal relationship. First, confirmatory factor analysis (CFA) was performed using PLS-SEM to test model fitness and evaluate the reliability and validity of the variables. In a second step, the theoretical relationship was tested. Factor analysis was conducted to distill and group the factors. Cronbach's alpha and composite reliability was used to assess and analyze the reliability of the construct. Convergent validity was assessed using AVE while discriminate validity was evaluated by examining cross loading. After ensuring that the model had an adequate fit, a conceptual model was tested. Hayes and Preacher's macro was used for mediation analysis.

\section{Results}

\section{I Descriptive statistics}

The majority of the branch managers of the sample banks have a formal business 
education. $57 \%$ of the branch managers hold an MBA degree while $4 \%$ have a BBA degree, indicating that, overall, $61 \%$ of the branch managers have a formal business education. This indicates that the branch establishments of the sample banks are competent and have basic foundation knowledge for performing the HRM responsibility. $62 \%$ of the respondents are between the age of 30 and 40, illustrating that the majority of the respondents are young. It is generally perceived that younger people are more likely to use and adapt to technology enabled systems. So, there is confidence that this study's respondents can provide quality responses for the purposes of the research.

\subsection{Measurement model}

The first step in PLS-SEM to estimate a conceptual model is factor analysis to specify how a group of indicators is related with its latent variable to ensure that valid and reliable measures are used to test the significance of the relationship (Chin, 1998). Table 2 shows that the indicators and latent variable are correlated. The t-value in Table 1 illustrates that all the factors are significantly loaded in their respective latent variable. Hair, Hult, Rungle, and Sarstedt (2016) suggested that an outer loading of a factor of less than 0.40 should not be retained for further analysis. Table 1 shows that factor loading was greater than the cutoff ensuring indicator reliability. Cronbach's alpha and composite reliability (CR) are two criteria that are commonly used to evaluate internal consistency. The table shows that the Cronbach's alpha and CR are greater than the threshold value of 0.70 , indicating that the instrument is internally consistent and reliable. Convergent validity is also used to evaluate the correlation among the measuring item of the respective latent variable (LV). The study employed AVE, which is commonly used for evaluating convergent validity. As suggested by Hair, Hult, Ringle, and Sarstedt (2016), an AVE for all variables greater than 0.50 ensures convergent validity. Any item that did not fulfill the above criteria is excluded from further analysis. For example, REHRMP4 and REHRMP5 are deleted because they do not fulfill the criteria for the measurement model. With respect to control variables, it was observed that firm size ( $\beta=0.103$; $\mathrm{t}=3.479)$ has a significant and positive impact on employee productivity, whereas bank age has a significant and negative $(\beta=-0.191$; $\mathrm{t}=3.395$ ) impact on employee productivity. The implications of the control variables are further discussed in later sections.

\subsection{Hypotheses testing}

First, the study analyzed the direct relationship between e-HRM practices and QHRS. Wahyudi and Park (2014) found that quality of HR services is an important indicator for measuring the value creation aspect in the context of e-HRM; therefore, we used QHRS as a value creating (employee-productivity enhancing) factor. Figure 1 illustrates the direct relationship between the predictors and QHRS. 


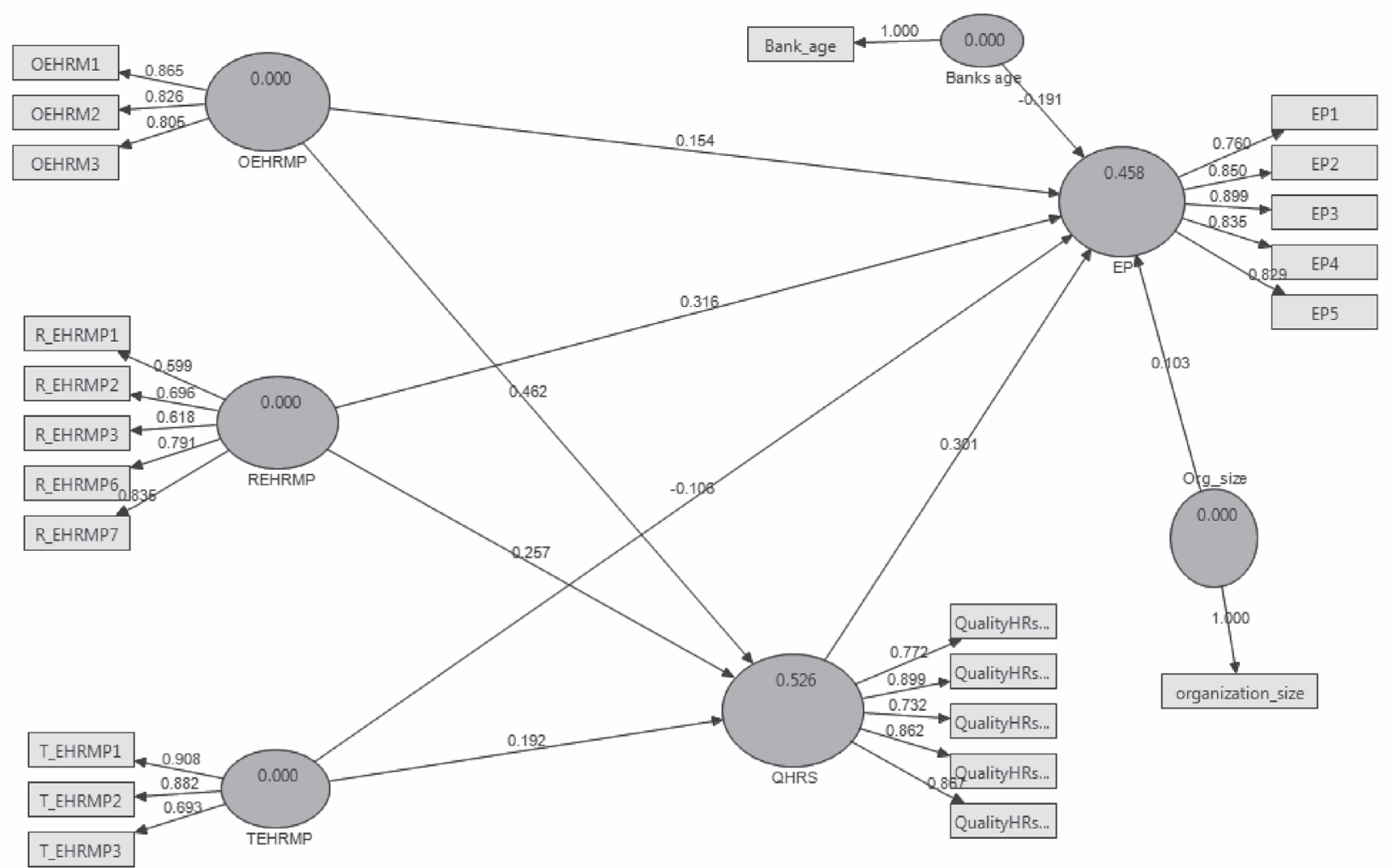

Figure 1. Study Model.

Table 2 shows that the relationship between operational e-HRM practices and QHRS is significant ( $\beta=0.4624 ; \mathrm{t}=7.7327)$. Therefore, $\mathrm{H} 2 \mathrm{a}$ is supported. Relational e-HRM practices have a positive and significant impact on QHRS $(\beta=0.2574 ; \mathrm{t}=4.3030) . \mathrm{H} 2 \mathrm{~b}$ is thus supported.
Transformational e-HRM practices have a significant, positive, and direct effect on QHRS $(\beta=0.1924 ; \mathrm{t}=4.8738)$. Hence, $\mathrm{H} 2 \mathrm{c}$ is supported. The predictors explained $52 \%$ of the variance in QHRS $\left(\mathrm{R}^{2}=0.52\right)$.

Table 2

\section{Direct effect testing}

\begin{tabular}{ccccc}
\hline Hypotheses & t-value & $\boldsymbol{B}$ & Hypothesized Relationship & Decision \\
\hline H1a & 2.4378 & 0.1541 & OEHRMP $>$ EP & Supported \\
H1b & 5.4081 & 0.3164 & REHRMP->EP & Supported \\
H1c & 2.7601 & -0.1065 & TEHRMP->EP & Supported \\
H2a & 7.7327 & 0.4624 & OEHRMP-> QHRS & Supported \\
H2b & 4.3030 & 0.2574 & REHEMP-> QHRS & Supported \\
H2c & 4.8738 & 0.1924 & TEHRMP->QHRS & Supported \\
H3 & 5.3605 & 0.3009 & QHRS $>$ EP &
\end{tabular}


To check the direct relationship between e-HRM and employee productivity, $\mathrm{H} 1 \mathrm{a}, \mathrm{H} 1 \mathrm{~b}$, and $\mathrm{H} 1 \mathrm{c}$ were formulated. The results of the structural model, shown in Table 2, support H1a, $\mathrm{H} 1 \mathrm{~b}$, and H1c. Operational e-HRM practices are positively associated with employee productivity $(\beta=0.1541, t=2.4378)$. Transformational e-HRM practices also have a significant relationship with employee productivity $(\beta=-0.1065$; $\mathrm{t}=2.7601$ ). Therefore, $\mathrm{H} 1 \mathrm{c}$ is partially supported. The relationship is significant and negative $(\beta=0.103 ; \mathrm{t}=3.479)$, thus the hypothesis is partially supported. Relational e-HRM practices have a strong direct and positive effect on employee productivity $(\beta=0.3164 ; \mathrm{t}=5.4081)$, thus $\mathrm{H} 1 \mathrm{~b}$ is supported. The predictors of employee productivity (EP) explain $45 \%$ of the variance in the dependent variable.

\subsection{Mediating test}

The study takes many steps to check the mediating effect. First, we test for a zero- order relationship between the variables to indicate whether mediation is possible (Barron and Kenny, 1986). As the direct relationship between the variables is significant, it fulfils the first condition of mediation. In a second step, the mediator was included in a PLS path model to check the significance of the indirect effect. The indirect effect, i.e. the relationship between predictors (OEHRM, REHRM, and TEHRM) and mediator (QHRS), as well as QHRS and the dependent variable (EP), was significant, thus fulfilling the second condition of mediation. In a third step, the VAF was estimated to determine the magnitude of mediation. Table 3 shows that QHRS partially mediates between OEHRM and EP, as well as between TEHRM and EP, as the VAF is 0.2313 and 0.54 , respectively. The VAF value of 0.20 illustrates that QHRS also mediates the relationship between REHRM and EP, as shown in Table 3.

Table 3

\section{Evaluating mediating effect}

\begin{tabular}{|c|c|c|c|c|c|c|}
\hline Hypothesis & Indirect relationship & t-value & $\begin{array}{c}\text { Indirect effect } \\
\left(\mathbf{a}^{*} \mathbf{b}\right)\end{array}$ & Total effect & VAF & Status \\
\hline \multirow{2}{*}{$\mathrm{H} 4$} & OEHRMP $\rightarrow$ QHRS & 7.7327 & \multirow{2}{*}{$\beta 2=0.0463$} & \multirow{2}{*}{$\beta 1=0.20046$} & \multirow{2}{*}{0.2313} & \multirow{2}{*}{ Partial Mediation } \\
\hline & QHRS-> EP & 5.3605 & & & & \\
\hline \multirow{2}{*}{$\mathrm{H} 5$} & REHRMP-> QHRS & 4.3030 & \multirow{2}{*}{$\beta 2=0.0774$} & \multirow{2}{*}{$\beta 1=0.3938$} & \multirow{2}{*}{0.20} & \multirow{2}{*}{ Partial Mediation } \\
\hline & QHRS->EP & 5.3605 & & & & \\
\hline \multirow{2}{*}{$\mathrm{H} 6$} & TEHRMP-> QHRS & 4.8738 & \multirow{2}{*}{$\beta 2=0.057$} & \multirow[t]{2}{*}{$\beta 1=0.1643$} & \multirow{2}{*}{0.54} & \multirow{2}{*}{ Partial Mediation } \\
\hline & QHRS->EP & 5.3605 & & & & \\
\hline
\end{tabular}

Table 4

\section{Operational Definition of Construct}

\begin{tabular}{ll}
\hline Construct & Operational definition \\
\hline e-HRM adopted & $\begin{array}{l}\text { The organization has implemented operational, relational, and transformational e-HRM for } \\
\text { managing human resources. }\end{array}$ \\
Quality in HR services & $\begin{array}{l}\text { Quality in HR services is described as the continuous improvement, standardization, accuracy, } \\
\text { and reliability of the delivery of HR services. } \\
\text { Productivity is a measure of efficiency, which is described as an improvement in efforts for } \\
\text { achieving organizational goals. }\end{array}$ \\
\hline
\end{tabular}




\section{Discussion}

One of the objectives of the study was to analyze whether e-HRM practices explain variability in employee productivity in the context of commercial banking in Pakistan. Our research highlighted the role of three different types of e-HRM practices and their linkages with QHRS and employee productivity. Though previous studies have identified the importance of e-HRM practices, the focus of those studies has not been on employee productivity. The results indicate that e-HRM practices have a significant relationship with employee productivity, which is consistent with other research (CedarCrestone, 2012, 2013).

The RBV has been increasingly used in the IT, information systems, and HRM context to theoretically examine the value proposition for organizational outcomes (Almarri \& Gardiner, 2014; Bharadwaj, 2000; Chuang \& Lin, 2017; Delery \& Roumpi, 2017; Devece et al., 2017; Parry, 2011; Sabiu et al., 2016; Wade \& Hulland, 2004; Wright et al., 2001; Yang, 2015). Employee productivity has been recognized as a key organizational goal for companies (CedarCrestone, 2013; Rad \& Kim, 2018; Schivardi \& Schmitz, 2018). One of the key objectives of this study is to examine whether e-HRM is able to improve employee productivity. The results of the study show a positive and significant impact of e-HRM on employee productivity. The positive association between these two constructs indicates that e-HRM is a valid resource for improving organizational performance, leading to competitive advantage. The IT value research also supports this finding by suggesting that productivity gains are key motivations for organizations to introduce technology-based management systems.

Both of the control variables have a significant impact on employee productivity. The study found that bank size was a positive and significant predictor of employee productivity. Thus, large-sized banks were more likely to implement e-HRM and benefit from its outcomes.
The findings were consistent with previous studies (for example, Bell, Lee, \& Yeung, 2001; Lannelongue, Gonzalez-Benito, \& Quiroz, 2017; Parry, \& Tyson, 2011). In the case of bank age, the study found that younger banks were more interested in implementing e-HRM and improving productivity.

Different e-HRM practices influence organizational outcomes differently due to their variable impacts (Bissola \& Imperatori, 2013). In this study, we used a deterministic perspective to examine the impact of e-HRM practices, in that technology-enabled practices are a "causal factor that is expected to create predictable, theoretically determined consequences" (Marler $\&$ Fisher, 2013, p. 20). This is the reason why we take operational, relational, and transformational e-HRM as predictors of QHRS and employee productivity. The findings of the study show that operational e-HRM has a positive and a significant relationship with employee productivity, but not as strongly as relational e-HRM practices do. Thus, relational e-HRM is an important part of the e-HRM concept. Therefore, organizations should investment more efforts in the design and implementation of relational e-HRM practices if they wish to improve employee productivity. Transformational e-HRM practices (TEHRMP) have a significant but negative relationship with employee productivity, thus our hypothesis $\mathrm{H} 1 \mathrm{c}$ was partially supported. The findings are supported by Bissola and Imperatori (2013), who found a negative and significant relationship between transformational e-HRM practices and employee commitment. This indicates that transformational e-HRM activities are generally related with the strategic character of the organization. The existing literature indicates that transformational e-HRM may impede the realization of e-HRM benefits such as employee productivity (Parry \& Tyson, 2011). Such practices may be valuable for strategic planning but not for improving employee productivity.

Furthermore, our study confirms a direct impact of operational, relational, and transformational E-HRM practices on QHRS. 
The results of the study are consistent with earlier studies. Strohmeier (2007) proposed that e-HRM increased the quality of HR tasks by sharing administrative burden and improving the accuracy of HR processes. Bondarouk and Ruel (2009) proved that e-HRM practices provide standardized and errorless HR services, improving service delivery modes and saving time and effort, leading to an improvement in the quality of HR processes. The study suggests that QHRS plays a central role in the e-HRM-employee productivity causal chain. The VAF value confirms that QHRS mediates the relationship between e-HRM practices and employee productivity. Based on interviews with one of the managers in the banks, we found that e-HRM practices provide errorless and reliable services to internal customers that also support the commercial bank's core function and thus contribute to enhancing the productivity of employees acting as strategic partners. It was also found that due to the globalization and internationalization of the banks, technologybased practices play a decisive role in the success of the organization. e-HRM practices that are designed according to workflow and operational processes have a strong impact on employee productivity.

\section{I Theoretical implications}

Our results indicate that e-HRM practices, categorized as operational, relational, and transformational, have the potential to improve employee productivity, which is one of the important contributions of our study. The study argued that adopting e-HRM practices improves the quality of HR processes, which in turn leads to higher employee productivity. Previous studies (for example, Ramezen et al., 2013; Wahyudi \& Park, 2014) have identified that e-HRM practices improve the quality of HR services. However, a number of authors have reported (see, for example, Ambrosini \& Bowman, 2009; Meijerink et al., 2016; Uen et al., 2012) that the ultimate goal of the HRM system is to achieve strategic outcomes for the organization, and a perception of quality HR services influence the e-HRM performance relationship. Thus, the study contributes to the RBV by suggesting that e-HRM practices improve employee productivity by enhancing quality HR services. Some previous studies treat the quality of HR services as a dependent variable (Ramezan et al., 2013; Wahyudi \& Park, 2014); however, this study extends the existing e-HRM models by identifying that QHRS mediates the relationship between operational, relational, and transformational e-HRM practices and employee productivity. e-HRM is a vital resource for any organization that can strengthen the employer-employee relationship. Thus operational, relational, and transformational e-HRM constitutes a system that creates a competitive advantage for firms.

\subsection{Managerial implications}

The research has some clear managerial implications. If managers want to achieve their strategic objectives, the mere introduction of e-HRM is not sufficient; rather, they need to take a holistic approach and increase the efficacy of the e-HRM system by focusing on the quality of the services offered by it. Furthermore, there is ample opportunity for the rest of the banks operating in Pakistan to adopt technology based on HRM systems to facilitate their employees and achieve their strategic objectives. Our findings show that firms should know the capabilities and efficiencies of the operational e-HRM as it directly influences the perception of HRM service quality and employee productivity. Moreover, relational e-HRM practices such as e-performance appraisal and grievance management practices improve perceptions of the employment relationship. At the same time, transformational e-HRM practices that focus on knowledge management processes such as knowledge access, sharing, and employee development are strong predictors of employee productivity. By adopting e-HRM practices, practitioners can add value to their organizations and thus the HR function can contribute to the achievement of strategic outcomes. 


\section{Conclusion}

We argued that investment in human resource management systems and practices is positively linked with employee productivity. Our results also support the notion that it is the quality of HR services in the e-HRM causal chain that plays an important role in enhancing employee productivity. The study provided empirical evidence that commercial banks in Pakistan that have adopted the e-HRM system had a positive increase in the productivity of their employees. In particular, we demonstrate that operational, relational, and transformational e-HRM practices have a crucial role to play in improving the quality of HR services and employee productivity. Though more studies are required to explore the influence of e-HRM on workforce performance and should include other aspects such as turnover, commitment, etc to provide conclusive findings about e-HRM performance linkages, this study provides a useful launching point for measuring the impact of e-HRM on employee productivity.

\section{Nota:}

1 The Workplace Employment Relations Study (WERS) is a study that has been conducted by the British Government over the last several decades, and it uses a management questionnaire related to employment issues. The measure related to employee productivity is drawn from this management questionnaire, which is: "I believe that the productivity of our employees is better than that of our competitors" (as shown in table 1).

\section{References}

Ahmad, M., \& Allen, M. M. C. (2015). High performance HRM and establishment performance in Pakistan: An empirical analysis. Employee Relations, 37(5), 506 - 524.

Almarri, K., \& Gardiner, P. (2014). Application of resource-based view to project management research: Supporters and opponents. Procedia - Social and Behavioral Sciences, 119, 437-445.

Ambrosini, V., \& Bowman, C. (2009). What are dynamic capabilities and are they a useful construct in strategic management?. International journal of management reviews, 11(1), 29-49.

Barney, J. (1991). Firm resources and sustained competitive advantage. Journal of management, 17(1), 99-120.

Barron, J., Black, D., \& Lowenstein, M. (1993). Gender differences in training, capital and wages. Journal of Human Resources, 28(1),343-364.

Baron, R. M., \& Kenny, D. A. (1986), The moderator-mediator variable distinction in social psychological research: Conceptual, strategic, and statistical considerations. Journal of Personality and Social Psychology, 51(1), 1173-1182.

Bartel, A. P. (1995). Training, wage growth, and job performance: Evidence from a company database. Journal of Labor Economics, 13(3), 401-425.

Bashir, M. (2015). ICT-Banking Industry is the best beneficiary. Pakistan and gulf economist, 34(13), 11-12.

Beaton, D., Bombardier, C., Escorpizo, R., Zhang, W., Lacaille, D., Boonen, A., \& Tugwell, P. S. (2009). Measuring worker productivity: Frameworks and measures. Journal of Rheumatology, 36(9), 2100-2109.

Becker, B., \& Gerhart, B. (1996). The impact of human resource management on organizational performance: Progress and prospects. Academy of Management Journal, 39(4), 779-801.

Bell, B. S., Lee, S., \& Yeung, S. K. (2006). The impact of e-HR on professional competence in HRM: Implications for the development of HR professionals. Human Resource Management, 45(3), 295-308.

Bharadwaj, A. S. (2000). A resource-based perspective on information technology capability and firm performance: an empirical investigation. MIS Quarterly, 24(1), 169-196.

Bissola, R., \& B. Imperatori (2013). Facing e-HRM: The consequences on employee attitude 
towards the organisation and the HR department in Italian SMEs. European Journal of International Management, 7(4), 450-468.

Blanke, J., \& Chiesa, T. (2009). The travel \& tourism competitiveness report 2009. Geneva: World Economic Forum.

Bondarouk, T. V., \& Ruel, H. J. M. (2009). Electronic human resource management: Challenges in the digital era. The International Journal of Human Resource Management, 20(3), 505-514.

Bondarouk, T., \& Ruel, H. J. M. (2013). The strategic value of e-HRM: Results from an exploratory study in a governmental organization. The International Journal of Human Resource Management, 24(2), 391-414.

Bondarouk, T., Schilling, D., \& Ruel, H. (2016). E-HRM adoption in emerging economies: The case of subsidiaries of multinational corporations in Indonesia. Canadian Journal of Administrative Sciences, 33(2), 124-137.

Bondarouk, T., Harms, R., \& Lepak, D. (2017). Does e-HRM lead to better HRM service?. The International Journal of Human Resource Management, 28(9), 1332-1362.

Boselie, J. P., Dietz, G., \& Boon, C. (2005). Commonalities and contradictions in research on human resource management and performance. Human Resource Management Journal, 15(3), 67-94.

Bryson, A., Charlson, A., \& Forth, J. (2006). Worker voice, managerial response and labour productivity: An empirical investigation. Industrial Relations Journal, 37(5),438-455.

Burki, A. A., \& Niazi, G. S. K. (2009). Impact of financial reforms on efficiency of state owned, private and foreign banks in Pakistan. Applied Economics, 42(24), 3147-3160.

CedarCrestone (2012). CedarCrestone 2011-2012 HR Systems Survey-European
Highlights (14th Annual Edition). Retrieved from https://www.sierra-cedar.com/wpcontent/uploads/sites/12/2014/09/CC_20112012EuroSurveyHighlights.pdf

CedarCrestone (2013). CedarCrestone 2013-2014 HR Systems Survey: HR Technologies, Deployment Approaches, Value, and Metrics (15th Annual Edition). Retrieved from https://www.sierra-cedar. com/wp-content/uploads/sites/12/2014/07/ CC_2013-2014_HRS_Survey_WP.pdf

CedarCrestone (2017). 2016-2017 HR system survey white paper (19th Annual Edition). Retrieved from https://www.sierra-cedar. com/wp-content/uploads/sites/12/2016/10/ Sierra-Cedar_2016-2017_HRSystemsSurvey_ WhitePaper.pdf

Chin, W. (1998). Issues and opinions on structural equation modeling. MIS Quarterly, 22(1), 7-16.

Chuang, S. H., \& Lin, H. N. (2017). Performance implications of information-value offering in e-service systems: Examining the resource-based perspective and innovation strategy. The Journal of Strategic Information Systems, 26(1), 22-38.

Coronas, T. T., \& Oliva, M. A. (2009). Encyclopedia of human resources information systems: challenges in e-HRM. New York: Information Science Reference.

Deb, T. (2009). Managing human resource and industrial relation. New Dehli: Excel Books.

Delery, J. E., \& Shaw, J. D. (2001). The strategic management of people in work organizations: Review, synthesis, and extension. Research in Personnel and Human Resources Management, 20, 165-197.

Delery, J. E., \& Roumpi, D. (2017). Strategic human resource management, human capital and competitive advantage: is the field going in circles?. Human Resource Management Journal, 27(1), 1-21.

Devece, C., Palacios-Marqués, D., GalindoMartín, M. Á., \& Llopis-Albert, C. (2017). 
Information Systems Strategy and Its Relationship with Innovation Differentiation and Organizational Performance. Information Systems Management, 34(3), 250-264.

De Winne, S \& Sels L, (2003). 'HRM and performance', research without theory? a literature review. DTEW Research Report 0333,. 1-44.

Ejaz, S. K. (2012). Role of high performance work systems in SMEs (Dissertation of master). Foundation University: Pakistan.

Ehrhart, K. H., Witt, L. A., Schneider, B., \& Perry, S. J. (2011). Service employees give as they get: Internal service as a moderator of the service climate-service outcomes link. Journal of Applied Psychology, 96(2), 423-431.

Evans, W. R., \& Davis, W. D. (2005). Highperformance work systems and organizational performance: The mediating role of internal social structure. Journal of management, 31(5), 758-775.

Hair, J. F., Jr., Hult, G. T. M., Ringle, C., \& Sarstedt, M. (2016). A primer on partial least squares structural equation modeling ( $2 \mathrm{nd}$ ed). California: Sage Publications.

Hendrickson, A. R. (2003). Human resource information systems: Backbone technology of contemporary human resources. Journal of Labor Research, 24(3), 381-394.

Huselid, M. A. (1995). The impact of human resource management practices on turnover, productivity, and corporate financial performance. Academy of management journal, 38(3), 635-672.

Iqbal, N., Ahmad, M., Allen, M. M. C., \& Raziq, M. M. (2018). Does e-HRM improve labour productivity? A study of commercial bank workplaces in Pakistan. Employee Relations, 4O(2), 281-297.

Johnson, R. L., Tsiros, M., \& Lancioni, R. A. (1995). Measuring service quality: A systems approach. Journal of Services Marketing, 9(5), 6-19.
Khan, M. A. (2009). The potential and impact of perceived internal service quality in business process of pakistani banks and its relations to organizational performance (Doctrol thesis). National University of Modern Languages, Islamabad, Pakistan.

Khan, M. A., Rehman, K.,-Ur, Rehman, I.,-Ur, Safwan, N., \& Ahmad, A. (2011). Modeling link between internal service quality in human resources management and employees retention: A case of pakistani privatized and public sector banks. African Journal of Business Management, 5(3), 949-959.

Khilji, S. E., \& Wang, X. (2007). New evidence in an old debate: Investigating the relationship between HR satisfaction and turnover. International Business Review, 16(3), 377-395.

Koch, M. J., \& McGrath, R. G. (1996). Improving labor productivity: Human resource management policies do matter. Strategic management journal, 17(5), 335-354.

KPMG. (2013). Banking survey 2013. Pakistan: Autor. Retrivied from https://pt.scribd.com/ document/261535967/Banking-Survey-2013

Lannelongue, G., Gonzalez-Benito, J., \& Quiroz, I. (2017). Environmental management and labour productivity: The moderating role of capital intensity. Journal of environmental management, 190(1), 158-169.

Lempinen, H., \& Rajala, R. (2014). Exploring multi-actor value creation in IT service processes. Journal of Information Technology, 29(2), 170-185.

Lengnick-Hall, M. L., Lengnick-Hall, C. A., Andrade, L. S., \& Drake, B. (2009). Strategic human resource management: The evolution of the field, Human Resource Management Review, 19(2), 64-85.

Lengnick-Hall, M. L., \& Moritz, S. (2003). The impact of e-HR on the human resource management function. Journal of Labour Research, 24(3), 365-379. 
Lepak, D. P., Bartol, K. M., \& Erhardt, N. L. (2005). A contingency framework for the delivery of HR practices. Human Resource Management Review, 15(2), 139-159.

Lepak, D. P., \& Snell, S. A. (1998). Virtual HR: Strategic human resource management in the 21 st century. Human Resource Management Review, 8(3), 215-234.

Liao, H., Toya, K., Lepak, D. P., \& Hong, Y. (2009). Do they see eye to eye? Management and employee perspectives of high-performance work systems and influence processes on service quality. Journal of Applied Psychology, 94(2), 371-391.

Maatman, M., Bondarouk, T., \& Looise, J. K. (2010). Conceptualising the capabilities and value creation of HRM shared service models. Human Resource Management Review, 20(4) 327-339.

Marler, J. H., \& Fisher, S. L. (2016). The eHRM value proposition: Introduction to the special section. Canadian Journal of Administrative Sciences, 33(2), 91-94.

Marler, J. H. (2009). Making human resources strategic by going to the net: Reality or myth?. The International Journal of Human Resource Management, 20(3), 515-527.

Marler, J. H. \& Fisher, S. L. (2013). An evidence-based review of e-HRM and strategic human resource management. Human Resource Management Review, 23(1), 18-36.

Marler, J. H., \& Parry, E. (2016). Human resource management, strategic involvement and e-HRM technology. The International Journal of Human Resource Management, 27(19), 2233-2253.

Martin, G., Reddington, M., \& Alexander, H. (2008). Technology, outsourcing and transforming $H R$. London: Routledge.

Meijerink, J. G., Bondarouk, T., \& Lepak, D. P. (2016). Employees as active consumers of HRM:
Linking employees' HRM competences with their perceptions of hrm service value. Human resource management, 55(2), 219-240.

Mustafi, C. K., Pant, M., Rao, S., Shenoy,G. V., Viswanathan, P. K., Khurana, R. \& Chawala, D. (1999). Research methodology for management decision. Allama Iqbal Open University. Islamabad.

Noe, R. A., Colquitt, J. A., Simmering, M. J., \& Alvarez, S. A. (2003). Knowledge management: Developing intellectual and social capital. In S. E. Jackson, M. A. Hitt, \& A. S. Denisi (Eds). Managing Knowledge for Sustained Competitive Advantage (pp. 209-242). San Francisco, CA: Jossey-Bass.

Obeidat, S. M. (2016). The link between e-HRM use and HRM effectiveness: An empirical study. Personnel Review, 45(6), 1281-1301.

Panayotopoulou, L., Galanaki, E., \& Papalexandris, N. (2010). Adoption of electronic systems in HRM: Is national background of the firm relevant?. New Technology, Work and Employment, 25(3), 253-269.

Panos, S., \& Bellou, V. (2016). Maximizing e-HRM outcomes: A moderated mediation path. Management Decision, 54(5), 1088-1109.

Penrose, E. T. (1959). The theory of the growth of the firm. The Economic Journal, 71(281), 144-148.

Parry, E. (2011). An examination of e-HRM as a means to increase the value of the HR function. The International Journal of Human Resource Management, 22(5), 1146-1162.

Parry, E. \& Tyson, S. (2011). Desired goals and actual outcomes of e-HRM. Human Resource Management Journal, 21(3), 335-354.

Payne, S. C., Horner, M. T., Boswell,W. R., Schroeder, A. N., \& Stine-Cheyne, K. J. (2009). Comparison of online and traditional performance appraisal systems. Journal of Managerial Psychology, 24(6), 526-544. 
Purcell, J., \& Hutchinson, S. (2007). Front-line managers as agents in the HRM performance causal chain: Theory, analysis and evidence. Human Resource management journal, 17(1), 3-20.

Qutaishat, F. T., Khattab, S. A., Zaid, M. K. A., \& Al-Manasra, E. A. (2012). The effect of ERP successful implementation on employees' productivity, service quality and innovation : An empirical study in telecommunication sector in Jordan. International Journal of Business and Management, 7(19), 45-54.

Rad, K. G., \& Kim, S. Y. (2018). Factors Affecting Construction Labor Productivity: Iran Case Study. Iranian Journal of Science and Technology, Transactions of Civil Engineering, 42(2), 165-180.

Ramezen, M., Nazari, Y., \& Ahmadi, M. M. (2013). The effect of electronic human resources management on quality of services provided by human resources in the insurance industry (case study : Iran Insurance Company in Khorramabad City). Journal of Social Issues \& Humanities, 1(7), 223-232.

Ruel, H. J., Bondarouk, T. V, \& Van der Velde, M. (2007). The contribution of e-HRM to HRM effectiveness. Employee Relations, 29(3), 280-291.

Ruel, H., Bondarouk T., \& Looise, J. K. (2004). E-HRM: Innovation or irritation. An explorative empirical study in five large companies on webbased HRM. Management Review, 15(3), 364-380.

Sabiu, M. S., Mei, T. S., \& Joarder, M. H. R. (2016). Moderating role of ethical climates on HRM practices and organizational performance: A proposed conceptual model. Mediterranean Journal of Social Sciences, 7(1), 291-300

Sanayei, A. \& Mirzaei, A. (2008). Designing a model for evaluating the effectiveness of E-HRM (case study: Iranian organizations). International Journal of Information Science and Technology, 6(2), 79-98.

Schivardi, F., \& Schmitz, T. (2018). The IT Revolution and Southern Europe's Two Lost Decades. EIEF Working Paper, 1-65.
Snell, S. A., Pedigo, P. R., \& Krawiec, G. M. (1995). Managing the impact of information technology on human resource management. In G. R. Ferris, S. D. Rosan, \& D.T. Barnum (Eds.), Handbook of human resouce management, (pp. 159-174). Oxford: Blackwell.

Snell, S. A., \& Dean, J. W. (1992). Integrated manufacturing and human resource management: A human capital perspective. Academy of Management Journal, 35(3), 467-504.

Snell, S. A., Stuebner, D., \& Lepak, D. P. (2002). Virtual HR departments: Getting out of the middle. In R. L. Henneman \& D. B. Greenberger (Eds.), Human resource management in virtual organizations (pp. 81-101). Greenwich: Information Age Publishing.

Soteriou, A. C., \& Stavrinides, Y. (2000). An internal customer service quality data envelopment analysis model for bank branches. The International Journal of Bank Marketing, 18(5), 246-252.

State Bank of Pakistan (2013). Quarterly performance review of banking system. Pakistan: Autor.

Strohmeier, S. (2007). Research in e-HRM: Review and implications. Human Resource Management Review, 17(1), 19-37.

Strohmeier, S., \& Kabst, R. (2009). Organizational adoption of e-HRM in Europe: An empirical exploration of major adoption factors. Journal of Managerial Psychology, 24(6), 482-501.

Ulrich, D., \& Brockbank, W. (2005). The HR value proposition. Boston: Harvard Business School Press.

Uen, J. F., Ahlstrom, D., Chen, S. Y., \& Tseng, P. W. (2012). Increasing HR's strategic participation: The effect of HR service quality and contribution expectations. Human Resource Management, 51(1), 3-24.

Wade, M., \& Hulland, J. (2004). The resourcebased view and information systems research: 
Review, extension, and suggestions for future research. MIS Quarterly, 28(1), 107-142.

Wahyudi, E., \& Park, S. M. (2014). Unveiling the value creation process of electronic human resource management: An indonesian case. Public Personnel Management, 43(1), 83-117.

Wernerfelt, B. (1984). A resource-based view of the firm. Strategic management journal, 5(2), 171-180.

Wright, P. M., Dunford, B. B., \& Snell, S. A. (2001). Human resources and the resource based view of the firm. Journal of management, 27(6), 701-721.
Yang, T., Xun, J., \& He, X. (2015). British SMEs' e-commerce technological investments and firm performance: an RBV perspective. Technology Analysis \& Strategic Management, 27(5), 586-603.

Youndt, M. A., Snell, S. A., Dean, J. W., \& Lepak, D. P. (1996). Human resource management, manufacturing strategy, and firm performance. Academy of management Journal, 39(4), 836-866.

Zheng, C., \& Lamond, D. (2010). Organisational determinants of employee turnover for multinational companies in Asia. Asia Pacific journal of management, 27(3), 423-443.

\section{About the Authors:}

1. Naveed Iqbal, MS Management Sciences, COMSATS University Islamabad, Pakistan.

E-mail:Naveediqbal029@gmail.com

ORCID

(iD)0000-0003-0107-3298

2. Mansoor Ahmad, PhD (Manchester University, UK), COMSATS University Islamabad, Pakistan. Email: mansoor_ahmad@comsats.edu.pk

ORCID

(iD)0000-0002-2963-6315

3. Muhammad Mustafa Raziq, PhD (Massey University, New Zealand), COMSATS University Islamabad, Pakistan.

Email: mustafa@comsats.edu.pk

ORCID

(iD)0000-0002-7793-1597

4. Felipe Mendes Borini, PhD (University of Sao Paulo), FEA/USP, São Paulo, Brasil

E-mail: fborini@usp.br

ORCID

(DD0000-0003-1389-136X

\section{Contribution of each author}

\begin{tabular}{|c|c|c|c|c|}
\hline Contribution & $\begin{array}{c}\text { Naveed } \\
\text { Iqbal }\end{array}$ & $\begin{array}{c}\text { Mansoor } \\
\text { Ahmad }\end{array}$ & $\begin{array}{c}\text { Muhammad } \\
\text { Mustafa Raziq }\end{array}$ & $\begin{array}{l}\text { Felipe Mendes } \\
\text { Borini }\end{array}$ \\
\hline 1. Definition of research problem & $\sqrt{ }$ & $\sqrt{ }$ & $\sqrt{ }$ & $\sqrt{ }$ \\
\hline 2. Development of hypotheses or research questions (empirical studies) & $\sqrt{ }$ & $\sqrt{ }$ & $\sqrt{ }$ & $\sqrt{ }$ \\
\hline 3. Development of theoretical propositions (theoretical Work) & $\sqrt{ }$ & & & \\
\hline 4. Theoretical foundation/ Literature review & $\sqrt{ }$ & $\sqrt{ }$ & & \\
\hline 5. Definition of methodological procedures & & $\sqrt{ }$ & & \\
\hline 6. Data collection & $\sqrt{ }$ & & & \\
\hline 7. Statistical analysis & $\sqrt{ }$ & $\sqrt{ }$ & & \\
\hline 8. Analysis and interpretation of data & & & & $\sqrt{ }$ \\
\hline 9. Critical revision of the manuscript & & & $\sqrt{ }$ & \\
\hline 10. Manuscript Writing & $\sqrt{ }$ & & & \\
\hline 11. Other (proofing) & & & $\sqrt{ }$ & \\
\hline
\end{tabular}

